\title{
Foliar fertilization with molybdenum in wheat
}

\author{
Adubação foliar com molibdênio em trigo
}

\author{
Tiago Zoz ${ }^{*}$; Fábio Steiner ${ }^{1}$; João Vitor Paulo Testa ${ }^{2}$; Edleusa Pereira Seidel ${ }^{3}$; \\ Rubens Fey ${ }^{3}$; Deise Dalazen Castagnara ${ }^{4}$; André Zoz ${ }^{4}$
}

\begin{abstract}
The objective of this work was to evaluate the effect of foliar application of molybdenum on agronomic characteristics and yield of wheat in a no-till system. The experiment was carried out in a clayey Rhodic Hapludox, in Maripá, State of Paraná, Brazil. The experimental design was randomized blocks with five replications. Treatments consisted of four doses of molybdenum $\left(0,13.8,27.6\right.$ and $55.2 \mathrm{~g} \mathrm{ha}^{-1}$ Mo), divided into two foliar applications, the first at tillering (18 days after plant emergence) and the second at the boot stage (65 days after emergence). The foliar application of Mo up to a dose of $35 \mathrm{~g}$ $\mathrm{ha}^{-1}$ increased the number of spikes per square meter and yield of wheat; however, it had no effect on the agronomic characteristics of the crop in a no-till system.
\end{abstract}

Key words: Triticum aestivum, nitrogen, plants nutrition, micronutrient

\section{Resumo}

O trabalho teve como objetivo avaliar o efeito da aplicação foliar de molibdênio nas características agronômicas e na produtividade do trigo. O experimento foi conduzido em Maripá, PR, em Latossolo Vermelho de textura argilosa no sistema de semeadura direta. $\mathrm{O}$ delineamento experimental adotado foi em blocos ao acaso com cinco repetições. Os tratamentos constituíram de quatro doses de molibdênio $\left(0 ; 13,8 ; 27,6\right.$ e $55,2 \mathrm{~g} \mathrm{ha}^{-1}$ de Mo), divididas em duas aplicações foliares, a primeira no afilhamento (18 dias após a emergência das plantas) e a segunda no início do emborrachamento (65 dias após a emergência das plantas). A aplicação foliar de Mo até a dose de $35 \mathrm{~g} \mathrm{ha}^{-1}$ aumentou o número de espigas por área e a produtividade de grãos de trigo, porém, não teve efeito nas características agronômicas da cultura em sistema de semeadura direta.

Palavras-chave: Triticum aestivum, nitrogênio, nutrição de plantas, micronutriente

\footnotetext{
${ }^{1}$ Discentes do Dept ${ }^{0}$ de Produção Vegetal, Faculdade de Ciências Agronômicas, FCA. Universidade Estadual Paulista Júlio de Mesquita Filho, UNESP, Botucatu, SP. E-mail: tiagozoz@fca.unesp.br; fsteiner@fca.unesp.br

2 Discente do Dept ${ }^{\circ}$ de Engenharia Agrícola, FCA/UNESP. E-mail: joaovitorpt@hotmail.com

${ }^{3}$ Profs. do Centro de Ciências Agrárias, Universidade Estadual do Oeste do Paraná, UNIOESTE, Marechal Cândido Rondon, PR. E-mail: pseidel@unioeste.br; rubensfey@hotmail.com

${ }^{4}$ Discentes do Centro de Ciências Agrárias, UNIOESTE, Marechal Cândido Rondon, PR. E-mail: deisecastagnara@yahoo.com. br; andre_zoz@hotmail.com

* Author for corespondence
} 
Molybdenum (Mo) is an essential micronutrient for plant growth, especially for more demanding species in nitrogen or carrying out the process of biological nitrogen fixation (BNF). The importance of this micronutrient is due to its participation in the formation of nitrate reductase and nitrogenase enzymes, which play an important role in the synthesis of nitrogen assimilation in plants (TAIZ; ZEIGER, 2004).

This micronutrient is present in the soil, usually in the form of the molybdate ion $\left(\mathrm{MoO}_{4}^{2-}\right)$ (MENGEL; KIRKBY, 2001), and due to the deficiency of some natural soils, the removal by crops and failure to molybdic fertilizer by most producers are gradually depleting the natural resources of soil, which can affect the productive capacity of the cultures (FERREIRA et al., 2003). While plants need small amounts of Mo, many soils do not meet this demand. The total content of Mo in soils in the State of Paraná varies between 0.5 and $15.0 \mathrm{mg} \mathrm{kg}^{-1}$ and the amount available varies from 0.10 to $0.25 \mathrm{mg}$ $\mathrm{kg}^{-1}$ (SOUZA et al., 1996). The availability of Mo in the soil depends on the adsorption-desorption processes, which are influenced by soil $\mathrm{pH}$ and the content of $\mathrm{Fe}$ and $\mathrm{Al}$ oxides. The availability of Mo increases with increasing soil $\mathrm{pH}$ and acid soils with $\mathrm{pH}$ in water less than 5.0, the amount of Mo available to plants is extremely low (QUAGGIO et al., 1985).

Due to the high mobility in plants and of the application in small quantities, Mo can be provided via foliar application. However, the effectiveness of foliar application depends on the process of nutrient penetration through the cuticle, foliar uptake by cells and transport via phloem for preferential drains (RODRIGUES et al., 1997). Foliar applied Mo is rapidly absorbed by the leaves. Campo and Hungary (2002) found that translocation of Mo to the nodules of soybean plants was very rapid, and found the highest concentration of this nutrient in the nodules five days after application.

Ascoli, Soratto and Maruyama (2008) evaluated the effect of doses and application period of Mo, the leaves in common bean and obtained an increase in productivity with the application of up to $101.2 \mathrm{~g} \mathrm{ha}^{-1}$ of Mo from the which toxic effects were observed in culture, with reductions in yield. Calonego et al. (2010) found that the absence of supplemental Mo by foliar fertilization promoted the accumulation of nitrate in the leaves of the common bean as the increased availability of $\mathrm{N}$ in the soil, indicating the low efficiency of $\mathrm{N}$ assimilation in the absence of this nutrient. Thus, a wheat plant being demanding and responsive to nitrogen fertilization with Mo could be contributing to increase the efficiency of utilization of this nutrient to maximize the development and increasing crop productivity. However, there are no studies proving such an inference.

This study aimed to evaluate the effect of foliar application of molybdenum on agronomic characteristics and yield of wheat in a no-till system.

The experiment was carried out in Maripá, Paraná, Brazil ( $24^{\circ} 22^{\prime}$ S, $53^{\circ} 44^{\prime}$ W, altitude of $380 \mathrm{~m}$ ). The soil is a Rhodic Hapludox (Latossolo Vermelho eutroférrico in the Brazilian classification), with $775 \mathrm{~g} \mathrm{~kg}^{-1}$ of clay, $125 \mathrm{~g} \mathrm{~kg}^{-1}$ of silt, and $100 \mathrm{~g} \mathrm{~kg}^{-1}$ of sand. Samples were taken from the arable layer $(0-20 \mathrm{~cm})$, air dried, sieved through a $2.0 \mathrm{~mm}$ mesh, and analyzed as in Pavan et al. (1992). Soil chemical analysis showed $\mathrm{pH}\left(\mathrm{CaCl}_{2} 0.01 \mathrm{M}\right)$ : 5.0, O.M.: 28 $\mathrm{g} \mathrm{dm}^{-3}, \mathrm{P}_{\text {Mehlich-1 }}: 15 \mathrm{mg} \mathrm{dm}^{-3}, \mathrm{H}+\mathrm{Al}: 5.4 \mathrm{cmol}_{\mathrm{c}} \mathrm{dm}^{-}$ ${ }^{3}, \mathrm{~K}: 0.7 \mathrm{cmol}_{\mathrm{c}} \mathrm{dm}^{-3}, \mathrm{Ca}: 7.0 \mathrm{cmol}_{\mathrm{c}} \mathrm{dm}^{-3}, \mathrm{Mg}: 1.5$ $\mathrm{cmol}_{\mathrm{c}} \mathrm{dm}^{-3}$, CEC: $14.7 \mathrm{cmol}_{\mathrm{c}} \mathrm{dm}^{-3}, 63 \%$ of base saturation, $\mathrm{Cu}_{\text {Mehlich-1 }}: 15 \mathrm{mg} \mathrm{dm}^{-3}, \mathrm{Zn}_{\text {Mehlich-1 } 1}: 1.8 \mathrm{mg}$ $\mathrm{dm}^{-3}, \mathrm{Fe}_{\text {Mehlich-1 }}: 30 \mathrm{mg} \mathrm{dm}^{-3}$ and $\mathrm{Mn}_{\text {Mehlich-1 }}: 165 \mathrm{mg}$ $\mathrm{dm}^{-3}$. The area has been cultivated in tillage since 1996 and the area was planted with soybeans/winter corn and soybean/wheat, in the harvests 2006/07 and 2007/08, respectively.

The climate, according to Köppen classification, is Cfa, subtropical humid (mesothermal), with hot summers and a tendency towards high rainfall concentration (average temperature above 22 ${ }^{\circ} \mathrm{C}$ ) and winter with infrequent frosts (average 
temperature below $18 \mathrm{C}$ ) with no defined season, with average annual rainfall around 1,500 $\mathrm{mm}$. Rainfall data from during the experiment are shown in Figure 1.

Wheat sowing, CD 104 cultivar (medium cycle and low stature), was performed on 04/26/2008 with 350 seeds $\mathrm{m}^{-2}$ in $0.15 \mathrm{~m}$ spaced rows. The basic fertilization at wheat sowing was carried out by applying $500 \mathrm{~kg} \mathrm{ha}^{-1}$ 04-20-20 formulation and $80 \mathrm{~kg} \mathrm{ha}^{-1} \mathrm{~N}$ topdressing at the beginning of plants's tillering as urea. Pest and disease control was carried out with two applications of the products azoxystrobin + cyproconazole, methamidophos and lufenuron at $60 \mathrm{~g}$ a.i. ha ${ }^{-1}+24 \mathrm{~g}$ a.i. ha- ${ }^{-1}, 120 \mathrm{~g}$ a.i. $\mathrm{ha}^{-1}$ and $5 \mathrm{~g}$ a.i. ha ${ }^{-1}$, respectively.

Figure 1. Daily rainfall between April and August 2008 in Maripá, State of Paraná, Brazil. Sw - wheat sowing, $1^{\text {st }}$ and $2^{\text {nd }}-$ first and second foliar application, respectively, $\mathrm{Hw}$ - wheat harvest.

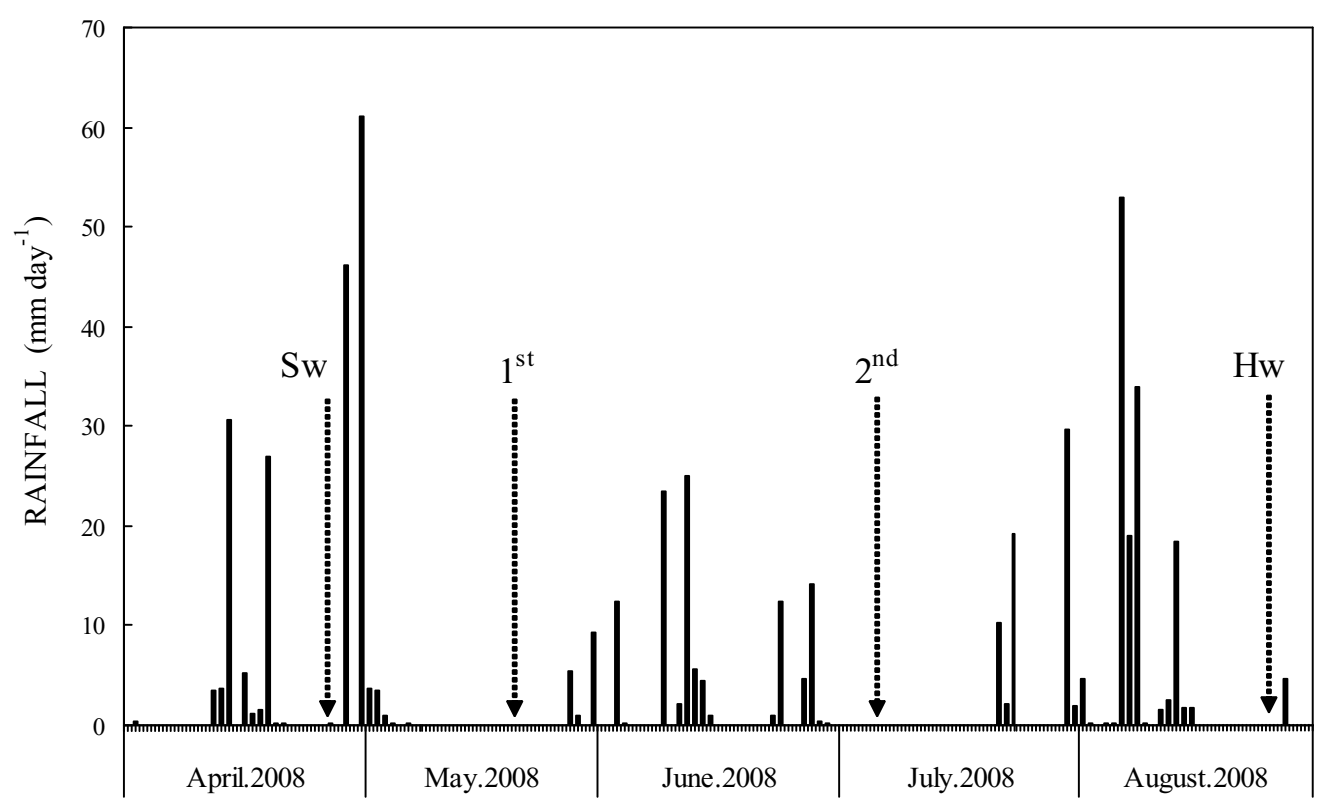

Source: Elaboration of the authors.

The experimental design was randomized blocks with five replications. Treatments consisted of four molybdenum doses $\left(0,13.8,27.6\right.$ and $55.2 \mathrm{~g} \mathrm{ha}^{-1}$ Mo), divided into two foliar applications, the first one at tillering (18 days after plants emergence) and the second at booting (65 days after plants emergence). The Mo source used was Omega Molibdênio $220^{\circledR}$ liquid fertilizer (16\% $\mathrm{Zn}$ and $84 \%$ inert material, with $1.38 \mathrm{~g} \mathrm{~mL}^{-1}$ density). Doses were defined according to the recommended product application to the wheat crop (27.6 $\left.\mathrm{g} \mathrm{ha}^{-1}\right)$. Applications were performed with a $\mathrm{CO}_{2}$ pressurized sprayer with $0.8 \mathrm{MPa}$ working pressure capacity, equipped with flat fan nozzle, adjusted to apply $165 \mathrm{~L} \mathrm{ha}^{-1}$ broth.
The applications were made at dusk due to a lower likelihood of drift by wind speed reduction and higher relative humidity. After each application, a minimum period of 72 hours (Figure 1) without rain was observed, enabling the best use of the product. Each experimental plot consisted of ten $6.0 \mathrm{~m}$ long rows, considering the six central lines as floor area, ignoring $1.0 \mathrm{~m}$ from the ends of each row.

Wheat harvest was performed manually on $08 / 27 / 2008$, collecting all plants contained in the working area. Agronomic characteristics of the crop were assessed against the following variables: plant height, flag leaf insertion height, stem diameter, number of spikes per square meter, length and 
spike weight, grain mass per spike, hectoliter weight (HW), thousand grain mass and grains yield corrected to $130 \mathrm{~g} \mathrm{~kg}^{-1}$ water content - wet basis.

Data were subjected to analysis of variance and regression, choosing the significant model with higher coefficient of determination $\left(\mathrm{R}^{2}\right)$.

Foliar application of molybdenum did not affect the variables of plant height, flag leaf insertion height, stem diameter, length and spike weight. These results are probably due to the fact that these features are predominantly determined by genetic factors, intrinsic to cultivating itself.

With the application of doses of Mo was obtained quadratic adjustment, so that the largest number of spikes per square meter was obtained with a dose of $37.5 \mathrm{~g} \mathrm{ha}^{-1}$ of Mo (Table 1). With the completion of the first application of Mo in the early tillering stage, shortly before being held to nitrogen fertilization, the number of tillers per plant increased, probably reflecting the greater efficiency of wheat plants in the synthesis of assimilation of $\mathrm{N}$ after topdressing. The second application was done at the early boot stage, causing the largest number of wheat tillers kept viable by the end of the cycle, thus providing increased number of spikes per unit area. This component production promoted an increased yield since it was only altered by the application of Mo and significantly correlated with grain production ( $\mathrm{r}$ $=0.75, \mathrm{p}<0.01)$.

Table 1. Plant height, flag leaf insertion height, stem diameter and number of spikes per square meter of wheat with foliar molybdenum application.

\begin{tabular}{|c|c|c|c|c|}
\hline Foliar Mo application & Plant height & $\begin{array}{c}\text { Flag leaf insertion } \\
\text { height }\end{array}$ & Stem diameter & $\begin{array}{c}\text { Number of spikes } \\
\text { per } \mathrm{m}^{2}\end{array}$ \\
\hline $\mathrm{g} \mathrm{ha}^{-1}$ & \multicolumn{2}{|c|}{ 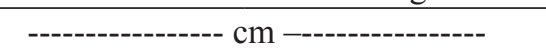 } & $\mathrm{mm}$ & units \\
\hline $0^{(2)}$ & 83.0 & 59.6 & 3.80 & 180.0 \\
\hline 13.8 & 84.2 & 59.8 & 3.80 & 262.3 \\
\hline 27.6 & 85.8 & 61.0 & 4.00 & 278.3 \\
\hline 55.2 & 86.8 & 62.8 & 4.00 & 269.6 \\
\hline Mean & 85.0 & 60.8 & 3.90 & 247.6 \\
\hline F test & $1.02 \mathrm{~ns}$ & $1.09 \mathrm{~ns}$ & $0.62 \mathrm{~ns}$ & $16.54 * *$ \\
\hline Regression & ns & ns & ns & $\mathrm{Q}^{* *(1)}$ \\
\hline CV $(\%)$ & 4.38 & 5.17 & 8.44 & 14.60 \\
\hline
\end{tabular}

ns: not significant. **: significant at $1 \%$. Q: quadratic equation. $\mathrm{CV}$ : coefficient of variation. ${ }^{(1)} \hat{\mathrm{y}}=184.3+5.90 \mathrm{x}-0.079 \mathrm{x}^{2}\left(\mathrm{R}^{2}=\right.$ 0.96). (2) Amount divided into two foliar applications, the first at tillering and the second in the early boot stage.

Source: Elaboration of the authors.

The thousand grains mass, the spike mass and hectoliter weight did not differ significantly depending on the doses of Mo (Table 2), possibly due to the increase in the number of spikes per $\mathrm{m}^{2}$ with increasing doses of Mo (Table 1). This result indirectly reflects the number of viable tillers, which may be considered physiologic sinks, thereby promoting the redistribution of assimilates between the existing drains in the plant. There was also no difference in the number of grains per spike.
There was an increase in wheat yield as a function of foliar fertilization with Mo (Table 2), and the maximum yield was obtained with a dose of $35.0 \mathrm{~g} \mathrm{ha}^{-1}$ Mo. From this dose there was a reduction in yield, probably due to the layering seen in the application of higher dose of Mo. The lodging occurred as a reflection of the increased number of spikes per square meter (Table 1), making the crop susceptible to lodging. 
Table 2. Spike length, spike mass, number of grains per spike, hectoliter weight, thousand grains mass and wheat yield with foliar molybdenum application.

\begin{tabular}{ccccccc}
\hline $\begin{array}{c}\text { Foliar Mo } \\
\text { application }\end{array}$ & Spike length & Spike mass & Grains per spike & $\begin{array}{c}\text { Hectoliter } \\
\text { weight }\end{array}$ & $\begin{array}{c}\text { Thousand } \\
\text { grains mass }\end{array}$ & Grain yield \\
\hline g ha $^{-1}$ & $\mathrm{~cm}$ & $\mathrm{~g} \mathrm{spike}^{-1}$ & units & & $\mathrm{g}$ & $\mathrm{kg} \mathrm{ha}^{-1}$ \\
$0^{(2)}$ & 8.80 & 5.67 & 56.8 & 78.8 & 30.2 & 2,415 \\
13.8 & 9.00 & 5.83 & 50.7 & 79.4 & 33.0 & 2,690 \\
27.6 & 9.00 & 5.84 & 50.4 & 78.8 & 33.0 & 2,737 \\
55.2 & 9.00 & 5.89 & 51.9 & 79.0 & 34.6 & 2,668 \\
Mean & 8.95 & 5.81 & 52.5 & 79.0 & 32.7 & 2,628 \\
\hline F test & $0.15 \mathrm{~ns}$ & $0.27 \mathrm{~ns}$ & $2.71 \mathrm{~ns}$ & $0.41 \mathrm{~ns}$ & $2.13 \mathrm{~ns}$ & $35.24^{* *}$ \\
\hline Regression & $\mathrm{ns}$ & $\mathrm{ns}$ & $\mathrm{ns}$ & $\mathrm{ns}$ & $\mathrm{ns}$ & $\mathrm{Q}^{* *(1)}$ \\
\hline CV $(\%)$ & 6.53 & 6.95 & 7.70 & 1.26 & 8.65 & 4.01 \\
\hline
\end{tabular}

ns: not significant. ${ }^{* *}$ : significant at $1 \%$. Q: quadratic equation. $\mathrm{CV}$ : coefficient of variation. ${ }^{(1)} \hat{\mathrm{y}}=2,428+20.1 \mathrm{x}-0.29 \mathrm{x}^{2}\left(\mathrm{R}^{2}=\right.$ 0.96). ${ }^{(2)}$ Amount divided into two foliar applications, the first at tillering and the second in the early boot stage.

Source: Elaboration of the authors.

Similar results were obtained in the study by Lima, Andrade and Carvalho (1999), in which the authors found that the application of $75 \mathrm{~g} \mathrm{ha}^{-1} \mathrm{Mo}$ increased the common beans yield and positively affected yield components in relation to the absence of enforcement. In corn, Valentini, Coelho and Ferreira (2005) evaluated the fertilization with $\mathrm{N}$ and Mo and observed an increase in yield with the application of Mo, with productivity increases of 44 and $12 \%$ in the absence and presence of nitrogen, respectively.

The foliar application of Mo up to a dose of 35 $\mathrm{g} \mathrm{ha} \mathrm{h}^{-1}$ increased the number of spikes per square meter and yield of wheat; however, it had no effect on agronomic characteristics of crops in a no-till system.

\section{References}

ASCOLI, A. A.; SORATTO, R. P.; MARUYAMA, W. I. Aplicação foliar de molibdênio, produtividade e qualidade fisiológica de sementes de feijoeiro irrigado. Bragantia, Campinas, v. 67, n. 2, p. 377-384, 2008.

CALONEGO, J. C.; RAMOS JUNIOR, E. U.; BARBOSA, R. D.; LEITE, G. H. P.; GRASSI FILHO, H. Adubação nitrogenada em cobertura no feijoeiro com suplementação de molibdênio via foliar. Revista Ciência Agronômica, Fortaleza, v. 41, n. 3, p. 334-340, 2010.
CAMPO, R. J.; HUNGRIA, M. Importância dos micronutrientes na fixação biológica do $\mathrm{N}_{2}$. Informações Agronômicas, Piracicaba, n. 98, p. 6-9, 2002.

FERREIRA, A. C. B.; ARAÚJO, G. A. A.; CARDOSO, A. A.; FONTES, P. C. R.; VIEIRA, C. Características agronômicas do feijoeiro em função do molibdênio contido na semente e da sua aplicação via foliar. Acta Scientiarum: Agronomy, Maringá, v. 25, n. 1, p. 65-72, 2003.

LIMA, S. F.; ANDRADE, M. J. B.; CARVALHO, J. G. Resposta do feijoeiro à adubação foliar de boro, molibdênio e zinco. Ciência e Agrotecnologia, Lavras, v. 23, n. 2, p. 462-467, 1999.

MENGEL K.; KIRKBY, E. A. Principles of plant nutrition. $5^{\text {th }}$ ed. Dordrecht, Kluwer: Academic Publishers, 2001. 849 p.

PAVAN, M. A.; BLOCH, M. F.; ZEMPULSKI, H. D.; MIYAZAWA, M.; ZOCOLER, D. C. Manual de análise química de solo e controle de qualidade. Londrina: Instituto Agronômico do Paraná, 1992. (Circular, 76).

QUAGGIO, J. A.; SAKAI, M.; ISHIMURA, I.; SAES, L. A.; BATAGLIA, O. C. Calagem para a rotação feijãomilho verde em solo orgânico do Vale do Rio Ribeira de Iguape (SP). Revista Brasileira de Ciência do Solo, Campinas, v. 9, n. 3, p. 255-261, 1985.

RODRIGUES, L. A.; SOUZA, A. P.; MARTINEZ, H. E. P.; PEREIRA, P. R. G.; FONTES, P. C. R. Absorção e translocação de zinco em feijoeiro aplicado via foliar. Revista Brasileira de Fisiologia Vegetal, v. 2, n. 9, p. 11$15,1997$. 
SOUZA, M. L. P.; ANDREOLI, C. V.; AMARAL, M. B.; VALENTINI, L.; COELHO, F. C.; FERREIRA, M. DOMASZAK, S. C. Levantamento preliminar dos teores de metais pesados em alguns solos do Paraná. Revista Sanare, Curitiba, v. 5, n. 5, p. 68-75, 1996.

TAIZ, L.; ZEIGER, E. Fisiologia vegetal. Porto Alegre: S. Teor de nitrogênio foliar e produtividade de três cultivares de milho (Zea mays) submetidos à adubação nitrogenada e molíbdica. Revista Ceres, Viçosa, v. 52, n. Artmed, 2004. 719 p. 302, p. 567-577, 2005. 